GRASAS Y ACEITES 69 (1)

January-March 2018, e241

ISSN-L: 0017-3495

https://doi.org/10.3989/gya.0997171

\title{
Variation in oil content and fatty acid composition of sesame accessions from different origins
}

\author{
C. $\operatorname{Kurt}^{\boxplus}$ \\ Cukurova University, Faculty of Agriculture, Dep. of Field Crop, Adana-Turkey \\ ${ }^{凶}$ Corresponding author: ckurt@cu.edu.tr
}

Submitted: 02 October 2017; Accepted: 13 December 2017

SUMMARY: Oil content and fatty acid composition are very important parameters for the human consumption of oilseed crops. Twenty-four sesame accessions including seven collected from various geographical regions of Turkey and 11 from different countries were investigated under field conditions for two consecutive years (2015 and 2016). The sesame accessions varied widely in their oil content and fatty acid compositions. The oil content varied between 44.6 and $53.1 \%$ with an average value of $48.15 \%$. The content of oleic acids, linoleic acid, linolenic acid, palmitic acid,and stearic acid varied between 36.13-43.63\%, 39.13-46.38\%, 0.28-0.4\%, 8.19-10.26\%, and $4.63-6.35 \%$, respectively. When total oil content and fatty acid composition were compared, Turkish sesame showed wide variation in oil and fatty acid compositions compared to those from other countries. However, the accessions from other countries were fewer compared to those from Turkey. It is essential to compare oil and fatty acid composition using a large number of germ plasm from different origins. In sesame oil, the average contents of oleic acid and linoleic acid were $39.02 \%$ and $43.64 \%$, respectively, and their combined average content was $82.66 \%$, representing the major fatty acid components in the oil from the sesame accessions used in the present study. The results obtained in this study provide useful information for the identification of better parents with high linoleic and oleic acid contents for developing elite sesame varieties with traits which are beneficial to consumer health.

\section{KEYWORDS: Fatty Acid; LDR; Linoleic Acid; ODR; Oil Content; Sesame}

RESUMEN: Variación en el contenido de aceite y composición de ácidos grasos de accesiones de sésamo de diferentes orígenes. El contenido de aceite y la composición de ácidos grasos de cultivos oleaginosos son parámetros muy importantes para el consumo humano. Veinticuatro accesiones de sésamo, incluidas siete recolectadas en diversas regiones geográficas de Turquía y once en otros países diferentes, se investigaron en condiciones de campo durante dos años consecutivos (2015 y 2016). Las accesiones de sésamo variaron ampliamente en su contenido de aceite y composiciones de ácidos grasos. El contenido de aceite varió entre 44,6 y 53,1\% con un valor promedio de $48,15 \%$. El contenido de ácido oleico, linoleico, linolénico, palmítico y esteárico variaron entre $36,13-43,63 \%, 39,13-46,38 \%, 0,28-0,4 \%, 8.19-10.26 \%$ y 4,63-6,35\% respectivamente. Cuando se compararon el contenido total de aceite y la composición de ácidos grasos el ajonjolí turco mostró una amplia variación en la composición del aceite y los ácidos grasos en comparación con los de otros países. Sin embargo, las adhesiones de otros países fueron menores en comparación con las de Turquía. Es esencial comparar la composición del aceite y de los ácidos grasos usando gran cantidad de germoplasma de diferentes orígenes. En aceites de sésamo, el contenido promedio de ácido oleico y ácido linoleico fue $39,02 \%$ y $43,64 \%$, respectivamente, y su contenido promedio combinado fue de $82,66 \%$ que son los ácidos grasos mayoritarios en los aceites de las accesiones de sésamo usadas en este estudio. Los resultados obtenidos proporcionan información útil para la identificación de mejores orígenes con alto contenido de ácido linoleico y oleico, para el desarrollo de variedades de sésamo de élite con características beneficiosas para la salud del consumidor.

PALABRAS CLAVE: Ácido graso; Ácido linoleico; Contenido de aceite; LDR; ODR; Sésamo

ORCID ID: Kurt C https://orcid.org/0000-0002-5030-4411

Citation/Cómo citar este artículo: Kurt C. 2108. Variation in oil content and fatty acid composition of sesame accessions from different origins. Grasas Aceites 69 (1), e241. https://doi.org/10.3989/gya.0997171

Copyright: (C2018 CSIC. This is an open-access article distributed under the terms of the Creative Commons Attribution 4.0 International (CC BY 4.0) License. 


\section{INTRODUCTION}

Sesame (Sesamum indicum L. - Pedaliaceae) is one of the oldest and most important oil seed crops known to mankind. Sesame was initially grown during the ancient Harappan, Mesopotamian, and Anatolian eras for its edible seed and oil (Bedigian, 2004) and is now grown in more than 60 countries. The origin of sesame (Sesamum indicum L.) continues to be debated, but evidence has shown that sesame originated in South Africa and India (Bedigian, 2004; Kobayashi, 1986; Yol and Uzun, 2012). In both circumstances, Turkey played a key role in the distribution of sesame (Uzun et al., 2008) since it was at a major crossroad of trade between the East and West in ancient times. Although there is a wide range of varieties and ecotypes of sesame adapted to various ecological conditions in Turkey, the cultivation of modern varieties is very limited owing to the lack of genetic information, especially about seed quality parameters.

Sesame seeds are used in bread, cakes, crackers and especially simit (ring-shaped bread) in commercial bakeries in Turkey. The seed is also made into tahin (sesame butter) and halva. In addition, it has been used in industries such as paint, pharmaceuticals, cosmetics, perfumery, insecticides and soap. Sesame seeds contain oil $(50 \%)$, protein (24\%) and micro elements (Fe, $\mathrm{Zn}, \mathrm{Ca}, \mathrm{Mg}$, Cu etc.). Compared to other oilseed crops, sesame yields superior oil quality and quantity, with its average oil content constituting approximately $50 \%$ of seed weight (Ashri, 1989). The sesame seed is commonly known as the 'Queen of oil seeds', probably due to its high nutritional and therapeutic value, and resistance to oxidation and rancidity (Johnson et al., 1979; Sukumar et al., 2008). In addition, sesame seeds contain a group of compounds called lignans, including sesamol, sesamolin, and sesamin, all known to have health benefits on account of their anti-tumorigenic, estrogenic and/or anti-estrogenic, hypocholesterolemic, antioxidant and hypoglycemic properties, along with their positive effect on sperm quality (Suja et al., 2005; Shittu et al., 2007; Shittu et al., 2008). Sesame ingestion (50 g sesame seed powder daily for 5 weeks) positively affected sex hormones, antioxidant status, and blood lipids in postmenopausal woman (Wu et al., 2006). The seed powder is useful in amenorrhea, dysmenorrhea, ulcers, and bleeding haemorrhoids (Kapoor 2001; Chandel et al., 1996).

In sesame oil, oleic and linoleic acids are the predominant fatty acids and constitute more than $80 \%$ of the total fatty acid content. The high level of monounsaturated and polyunsaturated fatty acids (PUFAs) increases the quality of the oil for human consumption (Mondal et al., 2010). Furthermore, the high levels of oleic acid and linoleic acid, PUFA, reduce blood cholesterol and the risk of cardiovascular diseases, and also play an important role in preventing atherosclerosis (Ghafoorunissa, 1994; Teres et al., 2008).

Sesame has been under cultivation in Asia for over 5,000 years and in Anatolia for over 1,000 years. There are numerous sesame populations adapted to different environments in this part of the world. These landraces are an important source of genetic variation for breeders. Information about genetic diversity is crucial in plant breeding programs because crosses between parents with high inter-parental diversity may help to develop varieties with a broad genetic base (Sing, 1990; Keneni et al., 2005). Insufficient genetic information about Turkish sesame populations is the main factor influencing the development of elite varieties (Baydar et al., 1999).

Although sesame is one of the most important oil crops in Turkey, very limited genetic and breeding studies have been conducted. Only 13 sesame cultivars have been registered in Turkey, despite good genetic variation and all of them being obtained via selection from breeding programs. Therefore, furhter genetic studies and determination of agro-morphologic and quality parameters of sesame populations in Turkey are required. Moreover, Turkey is a major importer of sesame seeds. For this reason, the characterization of valuable Anatolian sesame genetic resources is essential for the successful breeding of sesame with superior oil properties in Turkey.

The purpose of this study was to evaluate the variability in oil content and fatty acid composition among 24 sesame accessions from Turkey and 11 different countries. The study was performed over a period of two years. The information obtained will be useful to sesame breeders for planning efficient breeding strategies for new and improved varieties.

\section{MATERIALS AND METHODS}

\subsection{Plant material}

Twenty-four different sesame accessions (belonging to Turkey and 11 other countries) were used as plantmaterialin thisstudy(Table 1). The sesameaccessions were procured from the Aegean Agricultural Research Institute (Kahramanmaras, BalikesirKepsut, Mugla-Koycegiz, Kilis, Bursa-Orhangazi, Malatya-Ispendere, Orhangazi-99), United States Department of Agriculture (India, Afghanistan, Libya, Greece1, Greece 2, Zaire, USA, Egypt1, Egypt 2, Ethiopia) and the other seven were personally collected by the author (Iran1, Iran 2, Iran 3, Iran 4, Iran 5 (Tabriz), Iraq (Karkuk), and Pakistan (Multan)). The field experiment was conducted at the Experimental Farm of Cukurova University $\left(41^{\circ} 04^{\prime} \mathrm{N}, 36^{\circ} 71^{\prime} \mathrm{E}\right.$, and $\left.36 \mathrm{~m}\right)$, in Adana 
(Turkey) for two consecutive years in 2015 and 2016. In the Adana province, a typical Mediterranean climate prevails and the winters are warm and rainy whereas the summers are hot and dry. During the study period, monthly average day temperatures ranged from $25.0{ }^{\circ} \mathrm{C}$ to $30.0^{\circ} \mathrm{C}$ in 2015 and $27.1^{\circ} \mathrm{C}$ to $29.9^{\circ} \mathrm{C}$ in 2016 . The total rainfall was $146.1 \mathrm{~mm}$ and $93.8 \mathrm{~mm}$ during the growing periods in 2015 and 2016, respectively. The average relative humidity ranged from 63.4 to $69.8 \%$ in 2015 and 66.1 to $69.0 \%$ in 2016 (Table 2).

The experiments were conducted in a Randomized Complete Block design with three replications. Before planting, $200 \mathrm{~kg} \cdot \mathrm{ha}^{-1}$ of DAP $\left(36 \mathrm{~kg} \cdot \mathrm{ha}^{-1} \mathrm{~N}, 92 \mathrm{~kg} \cdot \mathrm{ha}^{-1} \mathrm{P}\right)$ fertilizers were applied. Ammonium nitrate $(33 \% \mathrm{~N})$ at the rate of 200 $\mathrm{kg} \cdot \mathrm{ha}^{-1}$ was applied once before the first irrigation. Twenty-four different sesame populations (belong to Turkey and different countries) were used as plant material in this study (Table 1). Sesame seeds were sown in the second week of June, 2015 and 2016. The accessions were grown in four row plots of $5 \mathrm{~m}$ row length with a row spacing of $70 \mathrm{~cm}$ and intra-row spacing of $15 \mathrm{~cm}$. Thinning was carried out after 25 days of sowing to secure one plant per

TABLE 1. The list of sesame accessions from different countries

\begin{tabular}{ll}
\hline Name of the germ plasm accession & Origin \\
\hline Kahramanmaras (T) & India \\
Balikesir-Kepsut (T) & Afghanistan \\
Mugla-Koycegiz (T) & Libya \\
Kilis (T) & Greece1 \\
Bursa-Orhangazi (T) & Greece 2 \\
Malatya-Ispendere (T) & Zaire \\
Orhangazi-99 (T)C & Iraq \\
Iran1 & USA \\
Iran2 & Pakistan \\
Iran3 & Egypt1 \\
Iran4 & Egypt 2 \\
Iran5 & Ethiopia \\
\hline
\end{tabular}

C: Cultivar; T: Turkey.
$15 \mathrm{~cm}$. Sprinkler irrigation was established immediately after sowing and thereafter used when necessary based on soil and plant conditions. Weeding was carried out by hand and no herbicides were applied during the growing seasons. All the plants were harvested in the last week of September, in 2015 and 2016.

\subsection{Oil extraction and GC analysis}

The samples of 24 genotypes grown in 2015 and 2016 were subjected to oil extraction using a Soxhlet apparatus and a gravimetric method. The experiments were performed in a Randomized Complete Block design with three replicates and seeds were bulked (20 g from each replication) and $5 \mathrm{~g}$ clean and mature seed samples were taken for oil content and fatty acid analysis. The oil content was determined by comparing the weights of $5 \mathrm{~g}$ seed samples before and after extraction using a Soxhlet apparatus (FOSS) with petroleum ether for $3 \mathrm{~h}$.

An oil sample of $500 \mathrm{mg}$ was dissolved in $2 \mathrm{ml}$ isooctane followed by $1.5 \mathrm{ml}$ of $0.5 \mathrm{M}$ methanolic $\mathrm{NaOH}$. The tube was then vortexed and held in boiling water for $7 \mathrm{~min}$ and allowed to cool to room temperature. Two $\mathrm{ml}$ of $\mathrm{BF} 3$ (Boron trifluoride) were added, vortexed, and held in boiling water for $5 \mathrm{~min}$ and allowed to come down to room temperature. The tube was vortexed after adding $5 \mathrm{ml} \mathrm{NaCl}$, centrifuge at $4,000 \mathrm{rpm}$ for $10 \mathrm{~min}$. The supernatant was used for GC analyses (AOAC 1984).

The fatty acid (FA) composition was analyzed using a GC Clarus 500 with auto sampler (Perkin Elmer, USA) equipped with a flame ionization detector and a fused silica capillary SGE column $(30 \mathrm{~m}$ $0.32 \mathrm{~mm}$, ID $0.25 \mathrm{~lm}$, BP20 0.25 UM, USA). The oven temperature was brought to $140{ }^{\circ} \mathrm{C}$ for $5 \mathrm{~min}$, then raised to $200{ }^{\circ} \mathrm{C}$ at a rate of $4{ }^{\circ} \mathrm{C} / \mathrm{min}$ and to $220{ }^{\circ} \mathrm{C}$ at a rate of $1{ }^{\circ} \mathrm{C} / \mathrm{min}$, while the injector and the detector temperatures were set at $220^{\circ} \mathrm{C}$ and 280 ${ }^{\circ} \mathrm{C}$, respectively. All analyses were performed in triplicate, and their means were reported. The data were statistically analyzed using a JUMP 8.1.0 statistical software package. The Least Significant Differences (LSD) test was used to compare the treatments at the 0.05 level.

TABLE 2. The average monthly temperature, monthly precipitation, and humidity during the 2015 and 2016 growing seasons in Adana-Turkey

\begin{tabular}{|c|c|c|c|c|c|c|}
\hline \multirow[b]{2}{*}{ Months } & \multicolumn{2}{|c|}{ Average Temperature $\left({ }^{\circ} \mathrm{C}\right)$} & \multicolumn{2}{|c|}{ Precipitation (mm) } & \multicolumn{2}{|c|}{ Humidity (\%) } \\
\hline & 2015 & 2016 & 2015 & 2016 & 2015 & 2016 \\
\hline June & 25.0 & 27.1 & 4.8 & 45.6 & 69.6 & 66.1 \\
\hline July & 28.4 & 29.5 & 0.4 & 0.2 & 69.8 & 67.5 \\
\hline August & 30.0 & 29.9 & 10.9 & 8.2 & 63.4 & 69.0 \\
\hline September & 28.4 & 26.3 & 130.0 & 39.8 & 64.8 & 61.8 \\
\hline
\end{tabular}




\subsection{Determination of fatty acid desaturation ratios}

Within the desaturation pathway, the oleic desaturation ratio (ODR) and the linoleic desaturation ratio (LDR) (Pleines and Friedt, 1988) were used to determine the efficiency of the desaturation from OA to LA (ODR) and from LA to ALA (LDR). They were calculated as follows:

$$
\begin{aligned}
& \mathrm{ODR}=\frac{\mathrm{C} 18: 2+\% \mathrm{C} 18: 3}{\% \mathrm{C} 18: 1+\% \mathrm{C} 18: 2+\% \mathrm{C} 18: 3} \\
& \mathrm{LDR}=\frac{\% \mathrm{C} 18: 3}{\% \mathrm{C} 18: 2+\% \mathrm{C} 18: 3}
\end{aligned}
$$

The data were statistically analyzed by One-Way ANOVA using the SPSS software.

\section{RESULTS AND DISCUSSION}

\subsection{Oil content and fatty acid profile}

The oil content and fatty acid composition in oilseed crops is affected by genotype, location, temperature, moisture content, growing conditions, planting date, fertilization, and the interaction these factors (Ul-Hassan and Ahmed, 2012).

A significant variation in oil content was found among the 24 sesame accessions as shown in Table 3 . The oil content of the 24 sesame accessions varied between $42.8-54.37 \%$ over a two-year period, the average being $47.7 \%$. The highest oil content was obtained from the Mugla-Koycegiz (T) Libya accession, whereas the lowest value was obtained from the Iran 1 accession. The range of oil content found was narrower than that in the Turkish (Uzun et al., 2008), worldwide (Yermanos et al., 1972), and

\begin{tabular}{|c|c|c|c|c|c|c|c|}
\hline & C16:0 & C18:0 & C18:1 & C18:2 & C18:3 & $C: 20$ & OC \\
\hline Kahramanmaras (T) & 9.60 & 4.93 & 39.11 & 43.38 & 0.28 & 0.53 & 48.53 \\
\hline Balikesir-Kepsut (T) & 9.65 & 5.06 & 39.60 & 42.76 & 0.31 & 0.55 & 49.50 \\
\hline Mugla-Koycegiz (T) & 10.26 & 4.79 & 37.24 & 44.48 & 0.36 & 0.52 & 53.50 \\
\hline Kilis (T) & 9.71 & 5.12 & 41.78 & 40.54 & 0.32 & 0.55 & 45.27 \\
\hline Bursa-Orhangazi (T) & 10.01 & 5.29 & 39.63 & 42.10 & 0.34 & 0.55 & 47.30 \\
\hline Malatya-Ispendere(T) & 9.91 & 5.31 & 39.46 & 42.50 & 0.29 & 0.54 & 45.57 \\
\hline Orhangazi-99 (T)C & 9.32 & 5.12 & 39.48 & 43.47 & 0.30 & 0.54 & 47.00 \\
\hline India & 9.43 & 4.98 & 41.27 & 40.93 & 0.29 & 0.55 & 43.93 \\
\hline Afghanistan & 9.33 & 5.16 & 37.59 & 45.07 & 0.28 & 0.54 & 46.67 \\
\hline Libya & 9.76 & 5.55 & 38.52 & 43.16 & 0.38 & 0.57 & 49.80 \\
\hline Greece 1 & 9.31 & 6.21 & 38.62 & 43.13 & 0.28 & 0.60 & 49.13 \\
\hline Greece 2 & 9.53 & 5.95 & 39.41 & 42.10 & 0.32 & 0.59 & 52.07 \\
\hline Egypt 1 & 8.96 & 4.97 & 37.48 & 45.80 & 0.40 & 0.53 & 51.53 \\
\hline Egypt 2 & 9.68 & 5.09 & 40.80 & 41.53 & 0.32 & 0.53 & 49.13 \\
\hline Ethiopia & 10.09 & 5.15 & 38.22 & 43.55 & 0.34 & 0.54 & 49.50 \\
\hline Zaire & 9.48 & 4.63 & 37.91 & 45.14 & 0.33 & 0.55 & 49.00 \\
\hline Iraq & 8.85 & 5.03 & 43.09 & 40.39 & 0.30 & 0.57 & 45.70 \\
\hline USA & 9.61 & 5.59 & 39.54 & 42.55 & 0.38 & 0.55 & 44.83 \\
\hline Iran 1 & 9.51 & 5.72 & 38.69 & 43.24 & 0.39 & 0.57 & 46.80 \\
\hline Iran 2 & 8.53 & 5.45 & 42.19 & 41.02 & 0.40 & 0.53 & 44.40 \\
\hline Iran 3 & 9.42 & 5.31 & 36.14 & 46.38 & 0.30 & 0.52 & 45.10 \\
\hline Iran 4 & 8.49 & 5.17 & 38.05 & 45.55 & 0.29 & 0.53 & 42.90 \\
\hline Iran 5 & 9.50 & 5.47 & 38.11 & 44.08 & 0.30 & 0.61 & 45.73 \\
\hline Pakistan & 8.70 & 5.70 & 41.76 & 41.19 & 0.28 & 0.54 & 51.10 \\
\hline Mean & 9.44 & 5.28 & 39.32 & 43.08 & 0.32 & 0.55 & 47.67 \\
\hline $\operatorname{LSD}(0.05)$ & $0.358^{* *}$ & $0.126^{* *}$ & $0.125^{* *}$ & $0.129^{* *}$ & $0.031^{* *}$ & $0.030^{* *}$ & $1.235^{* *}$ \\
\hline $\mathrm{CV}(\%)$ & 2.31 & 1.45 & 0.19 & 0.18 & 5.92 & 3.43 & 1.58 \\
\hline
\end{tabular}

TABLE 3. Oil contents and fatty acid compositions of sesame germ plasm of different countries in 2015

(T): Turkey; (C): Cultivar; OC: Oil Content; **: Significant at $\mathrm{p}<0.01$.

16:0: Palmitic acid; 18:0: Stearic acid; 18:1: Oleic acid; 18:2: Linoleic acid: 18:3: Linolenic acid; 20:0 Arachidic acid. 
Mediterranean core collection (Yol et al., 2015). These differences may have originated due to different genetic backgrounds and growing conditions.

The fatty acid compositions of the 24 sesame accessions are shown in Tables 3-5. In sesame oil, oleic acid and linoleic acid are the major fatty acids which form more than $80 \%$ of the total oil content. These were found in large amounts in the oil of all sesame accessions. The data belonging to the oil content and fatty acid composition for 2015, 2016 and in a two-year average are presented in Tables 3-5. Statistically significant differences were observed among the accessions for oil content and fatty acid composition in 2015, 2016 and in a two-year average. The oil contents varied between $42.9-53.5 \%$ in 2015 and between $42.8-54.37 \%$ in 2016 (Tables 3-4). According to a two-year average, the highest oil content was recorded for the Greece 2 (53.12\%) accession, while the lowest oil content was recorded for Iraq $(44.63 \%)$.
The highest oleic $(43.09 \%)$ and the lowest linoleic acid $(40.39 \%)$ percentages were obtained from the Iraq accession for 2015 and the highest linoleic acid $(46.38 \%)$ and the lowest oleic acid $(36.14 \%)$ percentages were obtained from the Iran 3 accession in 2015 (Table 3). The Kilis (T) accession had the highest oleic $(43.63 \%)$ and the lowest linoleic $(39.13 \%)$ acid contents; while the Libya accession had the higest linoleic $(46.13 \%)$ and the lowest oleic $(36.65 \%)$ acid contents in 2016 (Table 4). The oleic acid contents varied between 36.14 and $43.63 \%$ with a mean value of $39.02 \%$ (Table 5). Linoleic acid in sesame seed oil ranged from 36.13 to $46.38 \%$ with an average value of $43.64 \%$. The linoleic acid content was thus found to be higher than the oleic acid content in sesame seed oil. Oleic acid content percentages in earlier reports by Uzun et al., (2008) and Were et al., (2006) were lower than those in the present study, although they reported higher linoleic acid contents than that found in the present study.

TABLE 4. Oil content and fatty acid composition of sesame germplasm of different countries in 2016

\begin{tabular}{|c|c|c|c|c|c|c|c|}
\hline & C16:0 & C18:0 & C18:1 & C18:2 & C18:3 & C:20 & OC \\
\hline Kahramanmaras (T) & 8.90 & 5.20 & 37.73 & 45.49 & 0.29 & 0.51 & 48.60 \\
\hline Balikesir-Kepsut (T) & 9.45 & 5.14 & 39.45 & 43.10 & 0.30 & 0.54 & 43.30 \\
\hline Mugla-Koycegiz (T) & 9.52 & 5.31 & 37.75 & 44.51 & 0.32 & 0.55 & 49.90 \\
\hline Kilis $(\mathrm{T})$ & 8.53 & 5.89 & 43.63 & 39.13 & 0.29 & 0.58 & 47.77 \\
\hline Bursa-Orhangazi (T) & 9.02 & 5.52 & 40.93 & 41.51 & 0.31 & 0.55 & 51.40 \\
\hline Malatya-spendere(T) & 9.19 & 5.13 & 36.57 & 46.21 & 0.29 & 0.58 & 48.37 \\
\hline Orhangazi-99 (T)C & 9.09 & 5.26 & 38.63 & 44.31 & 0.30 & 0.54 & 48.60 \\
\hline India & 9.22 & 4.97 & 39.68 & 43.38 & 0.30 & 0.54 & 53.87 \\
\hline Afghanistan & 9.27 & 5.22 & 37.21 & 44.95 & 0.29 & 0.55 & 47.23 \\
\hline Libya & 9.39 & 4.97 & 36.65 & 46.13 & 0.34 & 0.56 & 54.37 \\
\hline Greece 1 & 8.80 & 6.35 & 38.32 & 43.56 & 0.34 & 0.60 & 45.67 \\
\hline Greece 2 & 9.30 & 5.04 & 38.25 & 44.62 & 0.33 & 0.57 & 54.17 \\
\hline Egypt 1 & 8.78 & 4.86 & 37.63 & 45.68 & 0.39 & 0.51 & 52.33 \\
\hline Egypt 2 & 9.35 & 5.76 & 38.91 & 43.30 & 0.32 & 0.57 & 54.07 \\
\hline Ethiopia & 9.46 & 4.90 & 37.89 & 45.04 & 0.32 & 0.55 & 49.37 \\
\hline Zaire & 8.88 & 5.13 & 38.38 & 44.97 & 0.35 & 0.57 & 45.43 \\
\hline Iraq & 8.67 & 5.45 & 40.39 & 42.72 & 0.29 & 0.56 & 43.57 \\
\hline USA & 9.10 & 4.76 & 37.26 & 46.15 & 0.32 & 0.54 & 50.80 \\
\hline Iran 1 & 9.15 & 5.53 & 38.84 & 43.66 & 0.37 & 0.58 & 42.80 \\
\hline Iran 2 & 8.19 & 5.35 & 40.22 & 43.75 & 0.35 & 0.53 & 46.30 \\
\hline Iran 3 & 8.19 & 5.63 & 40.80 & 42.88 & 0.31 & 0.58 & 45.70 \\
\hline Iran 4 & 8.62 & 5.32 & 37.84 & 45.67 & 0.34 & 0.53 & 47.37 \\
\hline Iran 5 & 8.85 & 5.07 & 37.43 & 45.89 & 0.33 & 0.58 & 48.40 \\
\hline Pakistan & 8.80 & 4.84 & 39.21 & 44.23 & 0.32 & 0.54 & 47.77 \\
\hline Mean & 8.99 & 5.27 & 38.73 & 44.20 & 0.32 & 0.55 & 48.63 \\
\hline $\operatorname{LSD}(0.05)$ & $0.159^{* *}$ & $0.153^{* *}$ & $0.148^{* *}$ & $0.148^{* *}$ & $0.022^{* *}$ & $0.024^{* *}$ & $1.184^{* *}$ \\
\hline CV (\%) & 1.08 & 1.77 & 0.23 & 0.20 & 4.27 & 2.64 & 1.48 \\
\hline
\end{tabular}

(T): Turkey; (C): Cultivar; OC: Oil Content; **: Significant at $\mathrm{p}<0.01$.

16:0: Palmitic acid; 18:0: Stearic acid; 18:1: Oleic acid; 18:2: Linoleic acid: 18:3: Linolenic acid; 20:0 Arachidic acid. 
TABLE 5. Oil content and fatty acid composition of sesame germ plasm of different countries in a two-year average

\begin{tabular}{|c|c|c|c|c|c|c|c|}
\hline & C16:0 & C18:0 & C18:1 & C18:2 & C18:3 & C:20 & OC \\
\hline Kahramanmaras $(\mathrm{T})$ & 9.13 & 5.20 & 39.14 & 43.77 & 0.29 & 0.52 & 48.57 \\
\hline Balikesir-Kepsut (T) & 9.45 & 5.09 & 39.16 & 43.43 & 0.31 & 0.55 & 46.40 \\
\hline Mugla-Koycegiz (T) & 9.77 & 5.07 & 38.17 & 43.97 & 0.34 & 0.53 & 51.70 \\
\hline Kilis (T) & 9.37 & 5.35 & 40.96 & 41.39 & 0.31 & 0.57 & 46.52 \\
\hline Bursa-Orhangazi (T) & 9.38 & 5.44 & 41.09 & 41.15 & 0.32 & 0.55 & 49.35 \\
\hline Malatya-Ispendere $(\mathrm{T})$ & 9.54 & 5.28 & 38.77 & 43.50 & 0.29 & 0.56 & 46.97 \\
\hline Orhangazi-99 (T)® & 9.32 & 5.20 & 38.71 & 44.04 & 0.30 & 0.54 & 47.80 \\
\hline India & 9.28 & 5.05 & 40.00 & 42.73 & 0.30 & 0.55 & 48.90 \\
\hline Afghanistan & 9.31 & 5.12 & 38.42 & 44.06 & 0.29 & 0.54 & 46.95 \\
\hline Libya & 9.48 & 5.24 & 37.52 & 44.76 & 0.36 & 0.57 & 52.08 \\
\hline Greece 1 & 9.23 & 5.94 & 38.17 & 43.78 & 0.31 & 0.60 & 47.40 \\
\hline Greece 2 & 9.29 & 5.76 & 38.71 & 43.35 & 0.33 & 0.58 & 53.12 \\
\hline Egypt 1 & 9.05 & 5.11 & 37.98 & 44.95 & 0.39 & 0.52 & 51.93 \\
\hline Egypt 2 & 9.30 & 5.25 & 39.08 & 43.52 & 0.32 & 0.55 & 51.60 \\
\hline Ethiopia & 9.69 & 5.16 & 38.65 & 43.67 & 0.33 & 0.55 & 49.43 \\
\hline Zaire & 9.38 & 4.93 & 38.11 & 44.80 & 0.34 & 0.56 & 47.22 \\
\hline Iraq & 8.90 & 5.12 & 40.54 & 42.72 & 0.30 & 0.57 & 44.63 \\
\hline USA & 9.15 & 5.20 & 39.51 & 43.42 & 0.35 & 0.55 & 47.82 \\
\hline Iran 1 & 9.34 & 5.47 & 38.64 & 43.75 & 0.38 & 0.58 & 44.80 \\
\hline Iran 2 & 8.68 & 5.47 & 40.39 & 42.74 & 0.38 & 0.53 & 45.35 \\
\hline Iran 3 & 8.65 & 5.45 & 39.38 & 43.88 & 0.31 & 0.55 & 45.40 \\
\hline Iran 4 & 8.63 & 5.32 & 38.12 & 45.28 & 0.32 & 0.53 & 45.13 \\
\hline Iran 5 & 8.97 & 5.26 & 37.83 & 45.19 & 0.31 & 0.59 & 47.07 \\
\hline Pakistan & 8.89 & 5.27 & 39.58 & 43.47 & 0.30 & 0.54 & 49.43 \\
\hline Mean & 9.21 & 5.28 & 39.03 & 43.64 & 0.32 & 0.55 & 48.15 \\
\hline $\operatorname{LSD}(0.05)$ & $0.402^{* *}$ & $0.337^{* *}$ & $1.315^{* *}$ & $1.706^{* *}$ & $0.019^{* *}$ & $0.019^{* *}$ & $0.8442^{* *}$ \\
\hline CV (\%) & 3.8 & 5.57 & 3.83 & 3.41 & 5.17 & 3.06 & 1.53 \\
\hline
\end{tabular}

(T): Turkey; (C): Cultivar; OC: Oil Content; **: Significant at $\mathrm{p}<0.01$.

16:0: Palmitic acid; 18:0: Stearic acid; 18:1: Oleic acid; 18:2: Linoleic acid: 18:3: Linolenic acid; 20:0 Arachidic acid.

Bhunia et al., (2015) reported that the percentage of oleic acid varied between 38 and $50 \%$, and that linoleic acid ranged from 18 to $43 \%$. Although linolenic acid is one of the most important unsaturated fatty acids, the linolenic acid content was very low in all sesame accessions varying from 0.28 to $0.40 \%$ (the highest in Iran1 and Iran 2), with an average of $0.32 \%$. Over a two-year period, the highest average oleic acid percentage was obtained from Kilis (T) $(43.63 \%)$ and the lowest from the Iran $3(36.14 \%)$ sesame accession. Over a two-year period, the highest average linoleic acid content was recorded in Egypt $1(45.74 \%)$, and the lowest was in the Kilis (T) (39.83\%) sesame accession (Table 5).Sesame has more unsaturated fatty acids than many other vegetable oils, and its higher proportion of unsaturated to saturated fatty acids makes it a potentially important dietary source of essential fatty acids (Bedigian, 2010). Linoleic acid is required for cell membranes, for transportation of cholesterol in the bloodstream, and for blood clotting (Salunkhe et al., 1991).

In the present study, the total content of these unsaturated fatty acids was $83.9 \%$. This value is similar to those reported by Uzun et al., (2008) (83.1\%) and Kurt et al., (2016) (83\%), higher than those reported by Bhunia et al., (2015) (75\%) and Yol et al., (2016) $(80.3 \%)$, and lower than those reported by Were et al., (2006) (85.9\%) and the World collection (Yermanos, 1972) (85.6\%). A high level of unsaturated fatty acids increases oil quality for human consumption.

Palmitic and stearic acids were the predominant saturated fatty acids in sesame oil, and were in the range of 8.19 to $10.26 \%$ and 4.63 to $6.35 \%$, respectively. Palmitic acid is used in industrial products such as soaps, esters, and plasticizers (Ndangui et al., 2010). 
Germ plasm, year and germ plasm $\mathrm{x}$ year effects were significant for all the fatty acids and oil contents. Most fatty acids did not differ significantly in their variation for the germ plasm $\mathrm{x}$ year interaction, while all the tested parameters showed significant variation in germ plasm (Table 6).

\subsection{Correlations among oil content and fatty acid composition}

Correlations between different traits are generally due to the presence of linked genes and the epistatic effect of different genes (Baloch et al., 2014). The results of the correlation analyses of oil content and fatty acids in the sesame accessions examined are shown in Table 7. Oil content was negatively and significantly correlated in oleic and stearic acids, but not in palmitic and linoleic acids. A similar relationship between oil content and oleic acid has been reported in sesame seeds (Yol et al., 2015; Were et al., 2006).

Stearic acid was significantly positively correlated with oleic and arachidic acid, while it had an inverse association with both linoleic and linolenic acids. Such an association was also reported by Yol et al., 2015. Linoleic acid was significantly negatively correlated with arachidic acid. Were et al., (2006) also reported a similar relationship between oleic and arachidic acids. Oleic acid had a strong negative correlation with linoleic acid $(r=-0.919)$ (Table 7). This was expected because linoleic acid is synthesized from oleic acid (Yol et al., 2015). A similar finding

TABLE 6. Variance analysis of oil contents and fatty acid compositions of 24 germ plasm over 2 years

\begin{tabular}{lccccccc}
\hline Variable & OC(\%) & $16: 0$ & $18: 0$ & $18: 1$ & $18: 2$ & $18: 3$ & $20: 0$ \\
\hline Accession & $* * *$ & $* *$ & $* *$ & $* * *$ & $* * *$ & $* * *$ & $* * *$ \\
Year & $* *$ & $* *$ & NS & $*$ & $* * *$ & $* * *$ & NS \\
Germ plasm x Year & $* * *$ & NS & $* *$ & NS & NS & NS & $* * *$ \\
\hline
\end{tabular}

$*$ :Significant at $\mathrm{p}<0.05 ; * *$ : Significant at $\mathrm{p}<0.01 ; * * *$ : Significant at $\mathrm{p}<0.001$; NS: non-significant OC: Oil Content; 16:0: Palmitic acid; 18:0: Stearic acid; 18:1: Oleic acid; 18:2: Linoleic acid: 18:3: Linolenic acid; 20:0 Arachidic acid.

TABLE 7. Correlation among fatty acid compositions (\% in oil) in different sesame accessions

\begin{tabular}{lcccc}
\hline & Palmitic & Stearic & Oleic & Linoleic \\
\hline Stearic & -0.152 & & & \\
Oleic & -0.096 & $0.304(* *)$ & & \\
Linoleic & -0.163 & $-0.403(* *)$ & $-0.919\left(^{* *}\right)$ & \\
Linolenic & 0.082 & -.058 & -0.133 & 0.149 \\
Arachidic & 0.036 & $0.432(* *)$ & 0.134 & $-0.232(* *)$ \\
\hline
\end{tabular}

$* *: 1 \%$. has been reported by other researchers for other oilseed crops including peanut (Mora-Escobedo et al., 2015) and soybean (Farno, 1996). The results indicated that different enzymatic processes of fatty acid synthesis are the principal determinant of the fatty acid composition in sesame seeds (Were et al., 2006). This inverse relationship between oleic and linoleic acids may be helpful in evaluating varieties that are rich in either oleic acid or linoleic acid (Pleines and Friedt, 1988; Baydar et al., 1999).

\subsection{Unsaturated fatty acids and their de-saturation ratios}

The nutritional quality of edible seed oils is determined ideally by the presence of a lower level of saturated fatty acids (SFA) [e.g. palmitic acid (C16:0), stearic acid (C18:0)], and a high level of unsaturated fatty acids [e.g. oleic acid (OA), linoleic acid (LA) and $\alpha$-linolenic acid (ALA)]. Variations in the UFA/SFA ratio in different accessions are shown in Table 8. Taking into account all fatty acids, the average content of unsaturated fatty acids was $83.93 \%$, the highest UFA value being obtained from the Iran $2(84.82 \%)$ accession. A high level of unsaturated fatty acids (UFA) enhances the quality of oil for human consumption. In particular, a high level of linoleic acid in the oil decreases blood cholesterol levels and plays an important role in preventing atherosclerosis (Ghafoorunissa, 1994). Among the accessions, the highest $\mathrm{O}: \mathrm{L}$ ratio was recorded in Kilis (T) (1.07); while the lowest was in Ethiopia (0.82).

It is difficult to evaluate suitable cultivars with beneficial health attributes solely on the basis of their phenotypic characteristics. The fatty acid biosynthetic pathway is highly inter-connected and any breeding modification will affect the entire system (Pleines and Friedt, 1988). Therefore, the two ratios were additionally developed and used to overcome this problem, the oleic de-saturation ratio (ODR) and the linoleic de-saturation ratio (LDR) (Bhunia et al., 2015; Mondal et al., 2015).

The variations in the ODR and LDR ratios are shown in Table 8. Among all the accessions, LDR values were found to be very low because of the low level of linolenic acid in sesame oil. The average ODR value was 0.53 , while the average LDR value was 0.007 . While the average ODR value found was higher than that reported by Bhunia et al., (2015) $(0.434)$ because of lower oleic acid content, the average LDR value was lower than that reported by Bhunia et al., (2015) (0.013) because of higher linoleic acid and lower linolenic acid contents. Mondal et al., (2010) reported that the mean value of ODR was 0.5 , while the mean value of LDR was 0.01 .

The oleic acid and linoleic acid ratio varied between 0.82 and 1.07. Among the accessions, the highest $\mathrm{O} / \mathrm{L}$ ratio was 1.07 in Kilis $(\mathrm{T})$, and the 
TABLE 8. Range of variation in de-saturation, $\mathrm{O} / \mathrm{L}$ acid, and UFA/SFA ratios in seed oil of different sesame accessions

\begin{tabular}{|c|c|c|c|c|}
\hline Germ plasm & UFA/SFA & $\mathrm{O} / \mathrm{L}$ & ODR & LDR \\
\hline Kahramanmaras (T) & 5.67 & 0.87 & 0.538 & 0.006 \\
\hline Balikesir-Kepsut (T) & 5.51 & 0.92 & 0.522 & 0.007 \\
\hline Mugla-Koycegiz (T) & 5.39 & 0.84 & 0.545 & 0.008 \\
\hline Kilis $(\mathrm{T})$ & 5.52 & 1.07 & 0.485 & 0.008 \\
\hline Bursa-Orhangazi $(\mathrm{T})$ & 5.39 & 0.96 & 0.511 & 0.008 \\
\hline Malatya-Ispendere $(\mathrm{T})$ & 5.46 & 0.86 & 0.540 & 0.007 \\
\hline Orhangazi-99 (T)C & 5.58 & 0.87 & 0.531 & 0.007 \\
\hline India & 5.64 & 0.89 & 0.512 & 0.007 \\
\hline Afghanistan & 5.65 & 0.96 & 0.548 & 0.006 \\
\hline Libya & 5.57 & 0.83 & 0.545 & 0.008 \\
\hline Greece 1 & 5.42 & 0.84 & 0.532 & 0.007 \\
\hline Greece2 & 5.39 & 0.94 & 0.529 & 0.007 \\
\hline Egypt 1 & 5.21 & 0.89 & 0.551 & 0.009 \\
\hline Egypt 2 & 5.39 & 0.90 & 0.517 & 0.007 \\
\hline Ethiopia & 5.92 & 0.82 & 0.540 & 0.007 \\
\hline Zaire & 5.45 & 0.86 & 0.543 & 0.007 \\
\hline Iraq & 5.78 & 0.85 & 0.501 & 0.007 \\
\hline USA & 5.80 & 1.01 & 0.538 & 0.008 \\
\hline Iran1 & 5.38 & 0.89 & 0.531 & 0.009 \\
\hline Iran2 & 5.94 & 0.97 & 0.509 & 0.009 \\
\hline Iran3 & 5.69 & 0.87 & 0.539 & 0.007 \\
\hline Iran4 & 5.92 & 0.83 & 0.548 & 0.007 \\
\hline Iran5 & 5.58 & 0.84 & 0.545 & 0.007 \\
\hline Pakistan & 5.80 & 0.95 & 0.515 & 0.007 \\
\hline
\end{tabular}

UFA: Unsaturated Fatty Acid; SFA: Saturated Fatty Acid; O:Oleic Acid; L:Linoleic Acid; ODR:Oleic Acid De-saturation Ratio; LDR: Linoleic Oleic Acid De-saturation Ratio;

lowest was 0.82 in Ethiopia because of higher linoleic acid contents. As can be seen in Table 8, the Turkish sesame accessions $\mathrm{O} / \mathrm{L}$ ratio was higher than other countries.

\section{CONCLUSION}

In this study, considerable variation was found in oil content and fatty acid composition among sesame accessions from different origins. The predominant unsaturated fatty acids were linoleic acid and oleic acid, and linoleic acid contents were higher than oleic acid in all sesame accessions except the Kilis $(\mathrm{T})$ accession. The Turkish sesame accessions' $\mathrm{O} / \mathrm{L}$ ratio was higher than other countries. Linoleic acid is an essential fatty acid for humans because it cannot be synthesized in the body but must be obtained from dietary sources. Sesame oil is considered a premium oil because it contains a high level of linoleic acid. The identified diversity in fatty acid contents is useful for the identification of better parents with high linoleic acid and oleic acid contents for developing elite sesame varieties with traits which are beneficial to consumer health. These sesame accessions are valuable in sesame breeding programs for high oil content and good fatty acid composition.

\section{REFERENCES}

AOAC, 1984. Official Methods of Analysis, 14th Ed., Assoc. of Official Analytical Chemists, Washington, DC

Ashri A. 1989. Sesame Oil crops of the world: their breeding and utilization. In: Robbelen G, Downey RK, Ashri A (eds) McGraw Hill, NY, pp 375-387.

Baloch FS, Karaköy T, Demirbaș A, Toklu F, Ozkan H, Hatipoglu R. 2014. Variation of some seed mineral contents in open pollinated faba bean (Vicia faba L.) landraces from Turkey. Turkish J. Agric. Forestry 38, 591-602. https:// doi.org/10.3906/tar-1311-31

Baydar H, Turgut I, Turgut K. 1999. Variation of certain characters and line selection for yield, oil, oleic acid and linoleic acid in Turkish sesame (Sesamum indicum L.) population. Turkish J. Agric. Forestry 23, 431-441.

Bedigian D. 2004. History and lore of sesame in Southwest Asia. Economic Botany 58, 329-353. https://doi. org/10.1663/0013-0001(2004)058[0329:AR]2.0.CO;2

Bedigian D. 2010. Medicinal and Aromatic Plants- Industrial Profiles: Sesame: The genus Sesamum. CRC press.

Bhunia RK, Chakraborty A, Kaur R, Gayatri T, Bhat KV, Basu A, Maiti MK, Sen SK. 2015. Analysis of Fatty Acid and Lignan Composition of Indian Germplasm of Sesame to Evaluate Their Nutritional Merits. J. Am. Oil Chem. Soc. 92, 65-76. https://doi.org/10.1007/s11746-014-2566-3

Chandel KPS, Shukla G, Sharma N. 1996. Biodiversity in Medicinal and Aromatic Plants in India: Conservation and Utilization. ICAR - NBPGR Publication, New Delhi, India.

Farno LA. 1999. Oil and Fatty Acid Profiles of Soybeans (Maturity Groups IV, V, AND VI). MSc. Thesis, Oklahoma State University.

Ghafoorunissa G. 1994. Dietary fats/oils and heart diseases. In: Prasad MVR (ed) Sustainability in oil seeds. Indian Society of Oil Seeds Research, Hyderabad, pp 486-490.

Johnson LA, Suleiman TM,Lusas EW. 1979. Sesame protein: a review and prospectus. J. Am. Oil Chem. Soc. 56, 463-468.

Kapoor LD. 2001. Handbook of Ayurvedic Medicinal Plants. Herbal Reference Library Edition, CRC Press, New York.

Keneni G, Jarso M, Wolabu T, Dino G. 2005. Extent and pattern of genetic diversity for morpho-agronomic traits in Ethiopian highland pulse landraces. II. Faba bean (Vicia faba L.). Genet. Resour. Crop Evol. 52, 551-561. https://doi. org/10.1007/s10722-003-6022-8

Kobayashi T. 1986. Goma no kita michi. [The Path of Sesame]. Iwanami Shoten, Japan. [in Japanese].

Kurt C, Arioglu H, Erdem T, Akkaya MR, El Sabagh A. Isalam, M.S. 2016. A comparative study of fatty acid extraction methods of sesame (Sesamum indicum L.) varieties grown under mediterranean environment. $J$. Experimental Biol. Agric. Sci. 4, October. https://doi. org/10.18006/2016.4(5S).588.593

Mondal N, Bhat VK, Srivastava SP. 2010. Variation in fatty acid composition in Indian germplasm of sesame. J. Am. Oil Chem. Soc. 87, 1263-1269. https://doi.org/10.1007/ s11746-010-1615-9

Ndangui CB, Kimbonguila A, Nzikou JM, Matos L, PambouTobi NPG, Abena AA, Silou T, Scher J, Desobry S. 2010. Nutritive composition and properties physico-chemical of gumbo (Abelmoschus esculentus L.) seed and oil. Res. J. Environ. Earth Sci. 2, 49-54.

Pleines S, Friedt W. 1988. Breeding for improved C18-fatty acid composition in rapeseed (Brassica napus L.). Fat Sci. Technol. 90, 167-171. 
Salunkhe DK, Chavan JK, Adsule RN. Kadam SS. 1991. World Oilseeds: Chemistry, Technology and Utilization. Springer, New York.

Shittu LA, Bankole MA, Oguntola JA, Ajala O, Shittu RK, Ogundipe OA. 2007. Sesame leaves intake improve and increase epididymal spermatocytes reserve in adult male Sprague Dawley rat. Sci. Res. Essay 2, 319-24.

Shittu LA, Adesite SO, Ajala MO, Bankole MA, Benebo AS, Tayo AO. 2008. Sesame Radiatum Phytoestrogenic Lignans Enhances Testicular Activity In Adult Male Sprague Dawley Rat Testis. Int. J. Morphol. 26, 643-52.

Suja KP, Jayalekshmy A, Arumughan C. 2005. In vitro studies on antioxidant activity of lignans isolated from sesame cake extract. J. Sci. Food. Agric. 85, 1779-83. https://doi. org/10.1002/jsfa. 2170

Terés S, Barceloì-Coblijn G, Menet M, Ailvarez R, Bressani R, Halver JE, Escribaì PV. 2008. Oleic acid content is responsible for the reduction in blood pressure induced by olive oil. Proc. Natl. Acad. Sci. USA 105, 13811-13816. https:// doi.org/10.1073/pnas.0807500105

Uzun B, Arslan C, Furat S. 2008. Variation in fatty acid compositions, oil content and oil yield in germplasm collection of sesame (Sesamum indicum L.). J. Am. Oil Chem. Soc. 85, 1135-1142. https://doi.org/10.1007/s11746-008-1304-0
Velasco L, Goffman FD, Becker HC. 1998. Variability for the fatty acid composition of the seed oil in a germplasm collection of the genus Brassica. Genet. Resour. Crop Evol. 45. 371-382. https://doi.org/10.1023/A:1008628624867

Were BA, Onkware AO, Gudu S, Welander M, Carlsson AS. 2006. Seed oil content and fatty acid composition in east African sesame (Sesamum indicum L.) accessions evaluated over 3 years. Field Crops Res. 97, 254-260. https://doi. org/10.1016/j.fcr.2005.10.009

Wu WH, Kang YP, Wang NH, Jou HJ, Wang TA. 2006. Sesame Ingestion Affects Sex Hormones, Antioxidant Status, and Blood Lipids in Postmenopausal Women. The Journal of Nutrition 136, 1270-1275.

Yermanos DM, Hemstreet S, Saeeb W, Uszar CK. 1972. Oil content and composition of the seed in the world of sesame. $J$. Am. Oil Chem. Soc. 49, 20-23.

Yol E, Uzun B. 2012. Geographical Patterns of Sesame (Sesamum indicum L.) Accessions grown under mediterranean environmental conditions, and establishment of a core collection. Crop Science 52, 2206-2214

Yol E, Toker R, Golukcu M, Uzun B. 2015. Oil Content and Fatty Acid Characteristics in Mediterranean Sesame Core Collection. Crop Sci. 55, September-October. https://doi. org/10.2135/cropsci2014.11.0771 